JURNAL RISET MAHASISWA AKUNTANSI

http://ejournal.unikama.ac.id/index.php/jrma

JRMA, Volume 6, No 2, Oktober 2018

\title{
Pengaruh Good Corporate Governance dan Leverage Terhadap Manajemen Laba
}

\author{
Yayuk Fanani \\ e-mail:yayukfanani22@gmail.com \\ Sulistyo \\ Rita Indah Mustikowati \\ (Program Studi Akuntansi, Fakultas Ekonomika dan Bisnis Universitas Kanjuruhan, \\ Malang)
}

\begin{abstract}
ABSTRAK
Penelitian ini bertujuan untuk mengetahui pengaruh good corporate governance dan leverage terhadap manajemen laba. Populasi yang digunakan dalam penelitian ini adalah perusahaan manufaktur yang terdaftar di Bursa Efek Indonesia tahun 2014-2015 dan metode penentuan sampel yang digunakan adalah purposive judgement sampling. Sampel yang diperoleh sebanyak 44 perusahaan. Teknik analisis data yang digunakan adalah analisis deskriptif, uji asumsi klasik, uji regresi linear berganda, dan pengujian hipotesis. Penelitian ini menemukan bahwa secara simultan good corporate governance dan leverage perusahaan berpengaruh terhadap manajemen laba. Secara parsial penelitian ini menemukan bahwa good corporate governance yang diproksikan oleh kepemilikan institusional (KI), kepemilikan manajerial (KM), komite audit (KA), ukuran perusahaan (UK), dan leverage berpengaruh terhadap manajemen laba, sedangkan dewan komisaris independen (DKI) dan dewan direksi (DD) tidak berpengaruh terhadap manajemen laba. Kata Kunci: Kepemilikan Institusional, Kepemilikan Manajerial, Dewan Komisaris Independen, Dewan Diresksi, Komite Audit, Ukuran Perusahaan, Leverage, Manajemen Laba
\end{abstract}

\begin{abstract}
This study aims to determine the effect of good corporate governance and leverage on earnings management. The population used is manufacturing companies listed on the Indonesia Stock Exchange in 2014-2015 and the sample determination method used is purposive judgment sampling. Samples obtained were 44 companies. Data analysis techniques used are descriptive analysis, classic assumption test, multiple linear regression test, and hypothesis testing. This study found that simultaneous good corporate governance and corporate leverage influence earnings management. Partially, this research found that good corporate governance is proxied by institutional ownership (KI), managerial ownership (KM), audit committee (KA), company size (UK), and leverage affect earnings management, while the independent board of commissioners (DKI) and the board of directors (DD) have no effect on earnings management.
\end{abstract}

Keynotes: institutional ownership (KI), managerial ownership (KM), board of directors, audit committee, company size, Leverage, earnings management 


\section{PENDAHULUAN}

Sulistyanto (2008) menyatakan secara umum manajemen laba (earnings management) didefinisikan sebagai upaya manajer perusahaan untuk mengintervensi atau mempengaruhi informasi-informasi dalam laporan keuangan dengan tujuan untuk mengelabuhi stakeholder yang ingin mengetahui kinerja dan kondisi perusahaan. Manajemen laba adalah potensi manajemen akrual untuk memperoleh keuntungan. Upaya perusahaan atau pihak-pihak tertentu untuk merekayasa, memanipulasi informasi, bahkan melakukan tindakan manajemen laba yang dapat menyebabkan laporan keuangan tidak lagi mencerminkan nilai fundamentalnya, karena laporan keuangan seharusnya berfungsi sebagai media komunikasi manajemen dengan pihak eksternal atau antara perusahaan dengan pemangku kepentingan.

Isu corporate governance muncul karena pemisahan antara pemilik perusahaan (pemegang saham) dengan pengelola perusahaan (manajemen) yang menimbulkan masalah (agency problems), permasalahan antara pemegang saham dengan manajemen adalah bagaimana sulitnya memastikan bahwa dana yang ditanam terinvestasikan secara benar sehingga mendatangkan keuntungan (return) yang maksimal bagi perusahaan. Good Corporate Governance diperlukan untuk mengurangi permasalahan keagenan tersebut.

Hamdani (2016) menyatakan ada dua sudut pandang yang mendefinisikan Good corporate governance yaitu sudut pandang dalam arti sempit (narrow viem) dan sudut pandang dalam pengertian lebih luas (broad view). Dalam susut pandang yang sempit, GCG diartikan sebagai hubungan yang setara antara perusahaan dan pemegang saham. Pada sudut pandang yang lebih luas, GCG sebagai a web of relationship, tidak hanya perusahaan dengan pemilik atau pemegang saham, akan tetapi perusahaan dengan pihak petaruh (stakeholders) lain yaitu: karyawan, pelanggan, pemasok, bondholders dan lainnya.

Leverage merupakan tingkat sejauh mana sekuritas dengan utang digunakan dalam struktur modal perusahaan. Leverage keuangan harus dianalisis untuk melihat sebaik apa dana ditangani, Bauran dana jangka pendek danjangka panjang yang diperoleh dari luar harus sesuai dengan tujuan dan kebijakan perusahaan. Jika penanganan dana tersebut tidak dilakukan dengan baik, maka leverage keuangan perusahaan dapat memicu pihak manajemen melakukan manajemen laba. Menurut penelitian Tampubolon (2015) dalam Ardiyansyah (2015) Leverage adalah perbandingan antara total kewajiban dengan total aktiva perisahaan. Rasio ini menunjukkan besarnya aktiva yang dimiliki perusahaan yang dibiayai dengan hutang. Semakin tinggi nilai leverage maka resiko yang akan dihadapi investor akan semakin tinggi dan para investor akan memimta keuntungan yang semakin besar. Leverage menunjukan proporsi penggunaan utang untuk membiayai investasinya. Semakin besar utang perusahaan maka semakin besar resiko yang dihadapi investor sehingga investor akan meminta tingkat keuntungan yang semakin tinggi. Akibatnya kondisi tersebut mendorong manajemen perusahaan untuk melakukan praktik income smoothing

Tujuan penelitian ini adalah untuk menguji dan menjelaskan secara simultan mekanisme GCG dan leveragePerusahaan terhadap manajemen laba, serta menguji dan menjelaskan secara parsial Kepemilikan Institusional, Kepemilikan Manajerial, Dewan Komisaris independen, Dewan Direksi, Komite Audit, Ukuran Perusahaan, leverage Perusahaan berpengaruh terhadap manajemen laba.

Berdasarkan latar belakang dan permasalahan tersebut maka judul dalam penelitian ini adalah Pengaruh Good Corporate Governance dan Leverage Terhadap Manajemen Laba pada Perusahaan Manufaktur yang terdaftar di Bursa Efek Indonesia (BEI) Tahun 20142015. 


\section{TINJAUAN PUSTAKA}

Manajemen laba merupakan campur tangan manajemen dalam proses penyusunan laporan keuangan yang tujuannya untuk dilaporkan kepada pihak eksternal dengan tujuan tertentu. Manajemen laba dapat mengurangi kredibilitas dari laporan keuangan karena tidak memcerminkan kondisi perusahaan yang sesungguhnya. Para pemakai laporan keuangan dimungkinkan akan mengambil keputusan yang salah di karenakan mereka memperoleh informasi keuangan yang salah (Abdillah, 2016).

\section{Pengaruh Good Corporate Governance dan Leverage terhadap Manajemen Laba}

Setiawan (2009) menyimpulkan bahwa secara simultan mekanisme good corporate governance berpengaruh secara simultan terhadap manajemen laba.Amperaningrum, Izzati dan Komala Sari, Intan (2013) menyimpulkan bahwa secara simultan ada pengaruh yang signifikan antara good corporate governance, leverage terhadap manajemen laba. Berdasarkan uraian tersebut, maka hipotesis yang diajukan sebagai berikut:

$\mathrm{H}_{1}$ : Good Corporate Governance dan Leverage berpengaruh terhadap manajemen laba

\section{Pengaruh Kepemilikan Institusional terhadap Manajemen Laba}

Kepemilikan institusional adalah kepemilikan saham perusahaan oleh institusi atau lembaga seperti perusahaan, asuransi, bank, perusahaan investasi dan kepemilikan institusi lain. Pemegang saham yang paling aktif adalah investor institusional (Ardiyansyah, 2015).

$\mathrm{H}_{2}$ : Kepemilikan institusional berpengaruh terhadap manajemen laba

\section{Pengaruh Kepemilikan Manajerial terhadap Manajemen Laba}

Kepemilikan manajerial merupakan persentase saham yang dimiliki oleh manajemen termasuk didalamnya persentase saham yang dimiliki oleh manajemen secara pribadi maupun dimiliki oleh anak cabang perusahaan yang bersangkutan beserta afiliasinya. Jensen \& Meckling (1976) menyatakan bahwa kepemilikan manajerial berhasil menjadi mekanisme untuk mengurangi masalah keagenan dari manajer dengan menyelaraskan kepentingan-kepentingan manajer dengan pemegang saham.

$\mathrm{H}_{3}$ : Kepemilikan Manajerial berpengaruh terhadap Manajemen Laba

\section{Pengaruh Dewan Komisaris Independen terhadap Manajemen Laba}

Pengaruh dewan komisaris dalam suatu perusahaan lebih ditekankan pada fungsi monitoring dari implementasi kebijakan direksi. Peran komisaris ini diharapkan akan meminimalisir permasalahan agensi yang timbul antara dewan direksi dengan pemegang saham. Oleh karena itu, dewan komisaris seharusnya dapat mengawasi kinerja direksi yang dihasilkan sesuai dengan kepentingan pemegang saham.

$\mathrm{H}_{4}$ : Dewan Komisaris Independen berpengaruh terhadap Manajemen Laba

\section{Pengaruh Dewan Direksi terhadap Manajemen Laba}

Dewan direksi mempunyai peran dan tanggung jawab yang penting dalam menentukan kebijakan yang akan dijalankan oleh perusahaan, baik dalam jangka waktu yang pendek maupun jangka panjang. Ukuran dewan direksi juga sebagai salah satu komponen good corporate governance yang sangat berperan penting dalam mengatasi manajemen laba. Keradaan dewan direksi tersebut sebagai mekanisme pengendali internal utama untuk memonitor para manajer perusahaan (Subhan, 2011). 
$\mathrm{H}_{5}$ : Dewan Direksi berpengaruh terhadap Manajemen laba

\section{Pengaruh Komite Audit terhadap Manajemen Laba}

Komite audit yang efektif diperlukan dalam pencapaian Good Corporate Governance. Ada beberapa manfaat dari pembentukan komite audit dalam perusahaan. Pertama, komite audit melakukan pengawasan laporan keuangan dan pelaksanaan audit eksternal. Kedua, komite audit melakukan pengawasan independen terhadap pengelolaan perusahaan. Ketiga, komite audit melaksanakan pengawasan independen atas proses pelaksanaan yang baik dalam mempengaruhi kualitas pelaporan keuangan yang pada akhirnya akan mempengaruhi manajemen laba (Herianto, 2013). $\mathrm{H}_{6}$ : Komite audit berpengaruh terhadap Manajemen Laba

\section{Pengaruh Ukuran Perusahaan terhadap Manajemen Laba}

Azlina (2010) menyatakan ukuran perusahaan adalah suatu skala dimana dapat diklasifikasikan besar dan kecilnya perusahaan dengan berbagai cara, antara lain: total aktiva, log size, nilai pasar saham, dan lain-lain. Semakin besar ukuran perusahaan, biasanya informasi yang tersedia untuk investor dalam pengambilan keputusan yang berhubungan dengan investasi dalam perusahaan tersebut semakin banyak.

$\mathrm{H}_{7}$ : Ukuran perusahaan berpengaruh terhadap Manajemen laba

\section{Pengaruh Leverage terhadap Manajemen Laba}

Rasio leverage menggambarkan sumber dana operasi yang digunakan oleh perusahaan. Rasio leverage juga menunjukkan risiko yang dihadapi perusahaan. Semakin besar risiko yang dihadapi oleh perusahaan, maka ketidakpastian untuk menghasilkan laba di masa depan juga akan semakin meningkat. Agustina (2010) menyatakan leverage ratio berpengaruh terhadap earnings management. Hasil ini menunjukkan bahwa perusahaan yang mempunyai rasio leverage yang tinggi, berarti proporsi hutangnya lebih tinggi dibandingkan dengan proporsi aktivanya akan cenderung melakukan manipulasi dalam bentuk manajemen laba.

$\mathrm{H}_{8}$ : Leverage berpengaruh terhadap Manajemen Laba

Dapat digambarkan kerangka konseptual pada gambar seperti berikut:

\section{Gambar 2.1 Kerangka Konseptual}

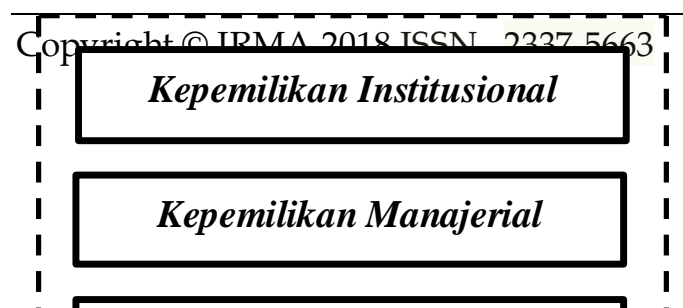




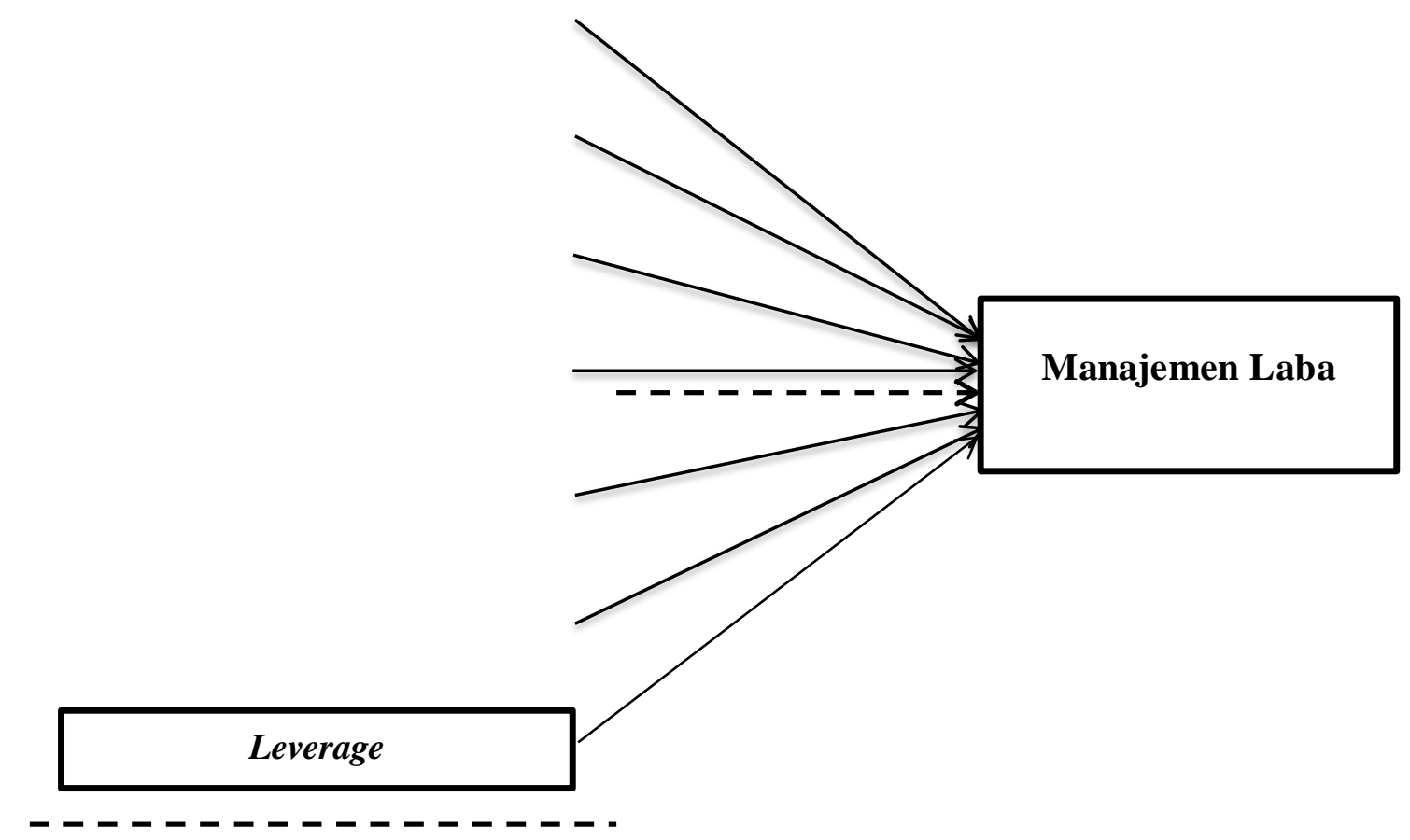

Sumber: Penelitian terdahulu

\section{METODE}

Jenis penelitian yang digunakan adalah explanatory research, yaitu menjelaskan hubungan kausal antara variabel-variabel penelitian melalui pengujian. Penelitian ini menggunakan metode penelitian kuantitatif. Metode ini disebut sebagai metode positivistik karena berlandaskan pada filsafat positivisme. Metode ini sebagai metode ilmiah karena telah memenuhi kaidah-kaidah ilmiah yaitu konkrit, obyektif terukur, rasional dan sistematis. Metode ini juga disebut metode discovery, karena dengan metode ini dapat ditemukan dan dikembangkan berbagai iptek baru. Metode ini disebut metode kuantitatif karena data penelitian berupa angka-angka dan analisis menggunakan statistik (Sugiyono, 2016:7).Berupa laporan tahunan perusahaan mnufaktur tahun 2014-2015, yang diperoleh dari situs BEI yang di akses melalui www.idx.co.id serta studi pustaka, jurnal dan lain-lain.

Teknik pengambilan sampel dalam penelitian ini menggunakan metode purposive sampling. Menurut Sugiyono (2016:85) purposive sampling adalah teknik penentuan sampel dengan pertimbangan tertentu. Sampel pada penelitian ini menggunakan beberapa kriteria sebagai berikut:

1. Perusahaan di Indonesia yang temasuk dalam golongan perusahaan manufaktur sesuai dengan kategori yang dikembangkan oleh Bursa Efek Indonesia yang tercantum dalam IDX selama tahun 2014-2015.

2. Perusahaan manufaktur tidak keluar (delisting) dari BEI selama tahun 2014-2015.

3. Perusahaan menerbitkan data laporan keuangan tahunan yang lengkap selama tahun pengamatan 2014-2015

4. Perusahaan yang tidak mengalami rugi selama tahun pengamatan 2014- 2015 
5. Perusahaan manufaktur yang memiliki laporan kepemilikan institusional, kepemilikan majerial, komisaris independen, ukuran dewan direksi, komite audit, ukuran perusahaan, dan rasio Leverage.

6. Perusahaan yang menggunakan mata uang rupiah.

Tabel 3.1

Seleksi Sampel Penelitian

\begin{tabular}{|r|l|r|}
\hline \multicolumn{1}{|c|}{ No } & \multicolumn{1}{|c|}{ Kriteria Sampel } & Jumlah \\
\hline 1. & Perusahaan Manufaktur yang terdaftar di BEI tahun 2014-2015 & 143 \\
\hline 2. & $\begin{array}{l}\text { Perusahaan manufaktur yang tidak memiliki kepemilikan } \\
\text { institusional, kepemilikan manajerial, dewan komisaris } \\
\text { independen, dewan direksi, komite audit, ukuran perusahaan, } \\
\text { dan leverage secara lengkap }\end{array}$ \\
\hline 3. & Perusahaan manufaktur yang mengalami rugi \\
\hline 4. Perusahaan yang tidak menggunakan mata uang rupiah & $(38)$ \\
\hline & Jumlah sampel & 22 \\
\hline
\end{tabular}

Sumber: Data diolah peneliti tahun 2016

\section{Definisi operasional dan pengukuran variabel}

Variabel dependen dalam penelitian ini adalah manajemen laba yang diukur oleh discretionary accrual. Untuk menghitung nilai discretionary accrual digunakan model Friedlan (dalam Wulan, 2013).

Secara formal perhitungannya adalah sebagai berikut:

1) Menghitung total accruals (TA) untuk periode $t$ dapat dinyatakan dengan persamaan sebagai berikut:

$$
\mathrm{TAC}_{\mathrm{T}}=\mathrm{NI}_{\mathrm{T}}-\mathrm{CFO}_{\mathrm{T}}
$$

Keterangan:

$\mathrm{TAC}_{\mathrm{T}}$ : total accruals pada periode $\mathrm{T}$

$\mathrm{NIT}_{\mathrm{T}} \quad$ : Laba bersih operasi (operating income) periode $\mathrm{T}$

CFOт : Aliran kas dari aktivitas operasi (cash flow from operating activities) pada akhir tahun $\mathrm{T}$

2) Mengukur Discretionary Accruals (DA) dengan menggunakan rumus:

$$
\mathrm{DAC}_{\mathrm{PT}}=\left(\mathrm{TAC}_{\mathrm{PT}} / \mathrm{SALE}_{\mathrm{PT}}\right)-\left(\mathrm{TAC}_{\mathrm{PD}} / \mathrm{SALE} \mathrm{PD}\right)
$$

Keterangan:

DAC ${ }_{\text {Pт }}$ : Discretionary accruals pada periode tes

TACPT : Total accruals pada periode tes

TACPD : Total accruals pada periode dasar

SALEpt : Penjualan pada periode tes

SALEPD : Penjualan pada periode dasar

Indikasi bahwa terjadi earnings management ditunjukkan oleh koefisien DAC yang positif, sebaliknya bila koefisien DAC negatif berarti tidak ada indikasi bahwa manajemen telah melakukan upaya menaikkan keuntungan melalui income-increasing discretionary accruals.

Variabel Independen $(X)$ dalam penelitian ini adalah: 
Kepemilikan institusional (institusional ownership) merupakan presentase kepemilikan saham perusahaan yang dimiliki investor institusional seperti pemerintah, perusahaan investasi, bank, perusahaan asuransi maupun kepemilikan lembaga dan perusahaan lain. Kepemilikan institusional diukur dengan persentase kepemilikan institusi dalam struktur saham perusahaan (Abdillah, 2016).

$$
\mathrm{IO}=\frac{\text { Jumlah lembar saham yang dimiliki Institusi }}{\text { Total lembar saham yang bererdar }} \times 100 \%
$$

Kepemilikan manajerial dalam penelitian ini diukur menggunakan presentase antara jumlah saham perusahaan yang dimiliki oleh pihak manajemen perusahaan terkait dengan total modal saham yang beredar di perusahaan (Abdillah, 2016).

$$
\mathrm{MO}=\frac{\text { Jumlah lembar saham yang dimilik manajen }}{\text { Total lembar saham yang beredar }} \times 100 \%
$$

Dalam penelitian ini proporsi dewan komisaris independen diukur menggunakan presentase antara jumlah anggota dewan komisaris yang berasal dari luar perusahaan dengan seluruh anggota dewan komisaris perusahaan (Guna dan Herawaty, 2010).

Dewan Komisaris Independen $=\frac{\text { Anggota dewan } \text { komisaris independen }}{\text { Total dewan } \text { komisaris }}$

Ukuran dewan direksi adalah jumlah anggota dewan direksi yang ada dalam perusahaan. Keberadaan dewan direksi tersebut bertugas sebagai mekanisme pengendali internal utama untuk memonitor para manajer perusahaan (Subhan, 2011).

Ukuran Dewan Direksi $=\sum$ Anggota Dewan Direksi

Komite audit dipilih oleh dewan komisaris untuk mengawasi sistem pengendalian akuntansi perusahaan. Keberadaan komite audit yang efektif mampu membuat kinerja perusahaan berjalan lebih baik. Komite audit dihitung dari jumlah anggota komite audit yang dimiliki (Abdillah, 2016).

Komite Audit $=\sum$ Anggota Komite Audit

Perusahaan yang besar lebih diperhatikan oleh masyarakat sehingga mereka akan lebih berhati-hati dalam melakukan pelaporan keuangan dan melaporkan kondisinya lebih akurat. Ukuran perusahaan diukur menggunakan logaritma natural dari total asset (Margaretha dan Ramadhan, 2011)

$$
\text { Size }=\text { Ln (Total assets) }
$$

Rasio leverage mengukur sejauh mana aset perusahaan telah dibiayai oleh penggunaan hutang. Semakin tinggi rasio leverage maka semakin banyak aset yang didanai hutang oleh pihak kreditur, sehingga menunjukkan resiko perusahaan dalam pelunasannya, hal ini dapat memicu terjadinya praktik manajemen laba. Leverage diukur dengan menggunakan rasio total utang terhadap total aset.

$$
\text { Leverage }=\frac{\text { Total Utang }}{\text { Total asset }}
$$

\section{Teknik Analisis Data}

1. Pengujian asusmsi klasik

Uji Normalitas

Uji normalitas bertujuan untuk mengetahui apakah dalam model regresi variabel penganggu memiliki distribusi normal. Selain itu, uji normalitas juga dapat diuji dengan statistik non-parametrik Kolmogorov Smirnov (K-S) dengan menggunakan taraf signifikansi 5\%. Jika, signifikansi (dapat dilihat pada Asymp. Sig. (2-tiled) pada output SPSS) dari nilai Kolmogorov Smirnov > 5\%, data yang digunakan berdistribusi normal (Ghozali, 2013).

Uji Multikolinieritas 
Uji multikolinearitas merupakan syarat yang digunakan dalam analisis regresi berganda yang digunakan untuk mengkaji ada korelasi atau tidak ada korelasi antar variabel independen. Multikolinearitas dalam model regresi dapat dilihat dari nilai variance inflation factor (VIF). Apabila nilai VIF lebih besar dari satu (VIF $>10$ ) menunjukkan adanya gejala multikolinearitas. Sedangkan, nilai VIF yang mendekati satu menunjukkan tidak adanya gejala multikolinearitas (Ghozali, 2013).

Uji Autokorelasi

Uji autokorelasi bertujuan untuk mengetahui hubungan yang kuat baik positif maupun negatif atau tidak ada hubungan antar data yang ada pada variabel-variabel penelitian dalam model regresi linier. Pengujian adanya autokolerasi dapat dilakukan menggunakan uji Durbin-Watson Test.

Uji Heteroskedastisitas

Uji heteroskedastisitas bertujuan untuk menguji dalam model regresi terjadi kesaman atau ketidaksamaan varian dari residual satu pengamatan kepengamatan yang lain. Jika variansi dari residual satu pengamatan ke pengamatan lain tetap maka disebut homoskedastisitas dan jika berbeda disebut heteroskedasitas. Uji heteroskedastisitas dapat dilakukan dengan melihat penyebaran dari varians residual. Jika ada pola tertentu, seprti titik-titik yang ada membentuk pola tertentu yang teratur maka mengindikasi telah terjadi heteroskedastisitas. Jika plot menyebar secara terpencar dan tidak membentuk pola tertentu maka dapat disimpulkan bahwa tidak terjadi masalah heteroskedastisitas (Ghozali, 2013).

\section{Analisis Regresi Linier Berganda}

Analisis regresi linier berganda digunakan untuk mengetahui arah hubungan antara variabel independen dengan variabel dependen, apakah masing-masing variabel independen berhubungan positif atau negatif danuntuk memprediksi nilai dari variabel dependen apabila nilai variabel independen mengalami kenaikan atau penurunan. (Sugiyono, 2012). Persamaan regresi linier berganda dapat dinyatakan sebagai berikut:

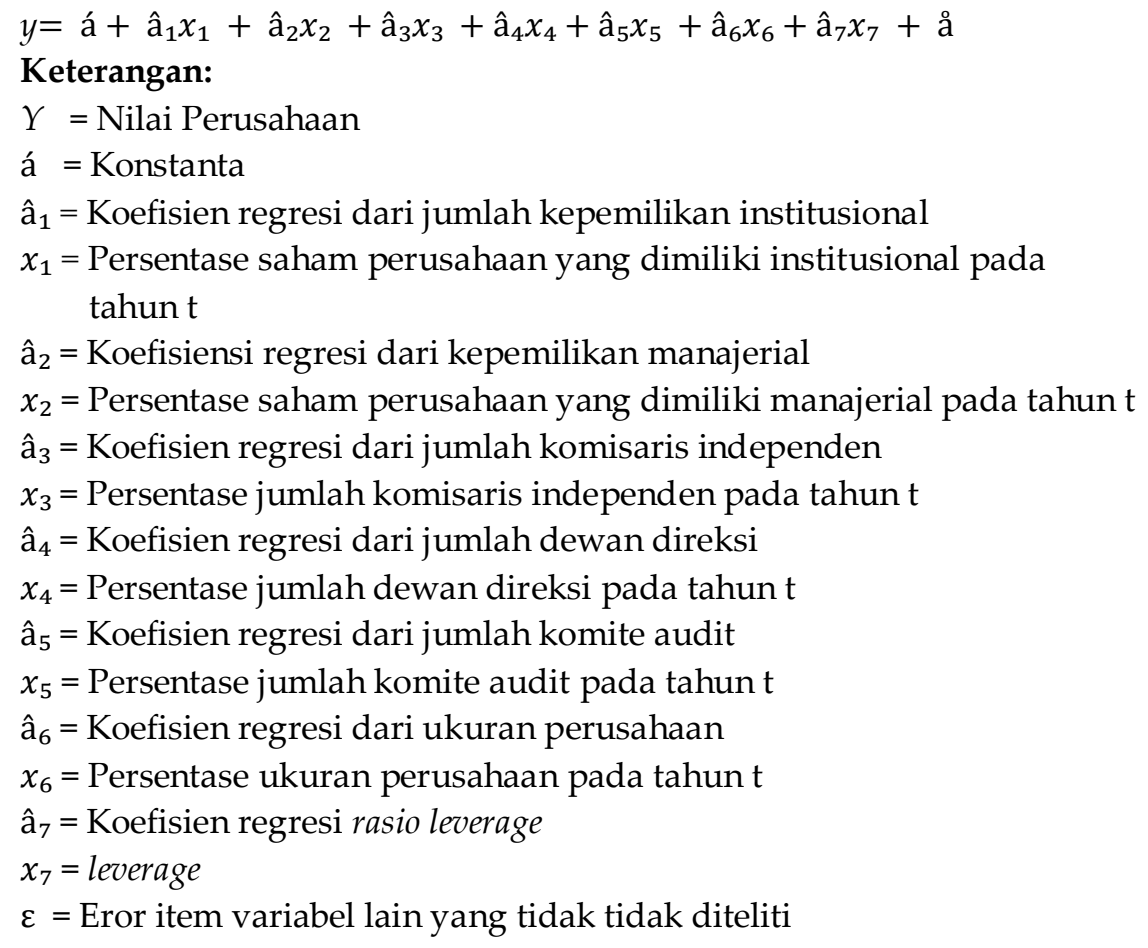




\section{Koefisien Determinasi Ganda $\left(\mathbf{R}^{2}\right)$}

Koefisien Determinasi (R2) digunakan untuk mengetahui seberapa jauh kemampuan suatu model penelitian dalam menjelaskan variasi variabel dependen yang ada. Dengan demikian akan diketahui seberapa besar variabel dependen dapat diterangkan oleh variabel independen yang ada. Nilai yang mendekati angka 1 berarti variabel independen hampir atau mampu memberikan informasi yang dibutuhkan untuk memprediksi variasi dependen (Ghozali, 2013).

\section{Pengujian Hipotesis}

$\underline{\text { Uji Parsial (Uji-F) }}$

Uji F dilakukan untuk mengatahui apakah variabel dependen secara bersamasama dipengaruhi oleh variabel independen. Pengujian dapat dilakukan dengan melihat tingkat signifikansi F. Menurut Ghozali (2013) hipotesis dapat diterima dan ditolak dengan melihat keriteria sebagai berikut: 1. Jika nilai signifikansi lebih besar dari 5\% maka hipotesis ditolak 2. Jika nilai signifikansi lebih kecil dari 5\% maka hipotesis diterima

Uji Parsial (Uji-T)

Uji ini dilakukan untuk mengetahui seberapa jauh variabel independen secara individu dalam menerangkan variabel dependen. Uji statistik $t$ digunakan untuk mengetahui apakah ada perbedaan yang terjadi antara variabel-variabel uji terhadap kelompok uji. Menurut Ghozali (2013) hipotesis dapat diterima dan ditolak dengan melihat keriteria sebagai berikut:

1. Jika nilai signifikansi lebih besar dari 0,05 maka hipotesis ditolak

2. Jika nilai signifikansi lebih kecil dari 0,05 maka hipotesis diterima.

\section{HASIL DAN PEMBAHASAN}

\section{Hasil Analisis Deskriptif}

\section{Manajemen Laba}

Nilai maximum manajemen laba pada tahun 2014 adalah APLI (Asiaplast Industries Tbk) sebesar 0.17 dan untuk tahun 2015 adalah SRSN (Indo Acitama Tbk) sebesar 0.17. Nilai minimum manajemen laba pada tahun 2014 adalah DPNS (Duta Pertiwi Nusantara) sebesar -0.38 dan untuk tahun 2015 adalah BTON (Beton Jaya Manunggal Tbk) sebesar 0,10. Rata-rata Manajemen Laba pada tahun 2014 adalah -0,02073 sedangkan pada tahun 2015 adalah $-0,00$.

Kepemilikan Institusional

Rata-rata jumlah Kepemilikan Institusional untuk tahun 2014 sebesar 0.879\% dan untuk tahun 2015 sebesar 0,887\%. Kemudian nilai tertinggi dari jumlah Kepemilikan Institusional untuk tahun 2014-2015 adalah LMPI (Langgeng Makmur Industry Tbk) yaitu sebesar 0,9998\%. Artinya semakin tinggi KI maka semakin baik dalam tata kelola perusahaan. Selanjutnya nilai terendah dari jumlah Kepemilikan Manajerial untuk tahun 2014-2015 adalah VOKS (Voksel Electric Tbk) yaitu sebesar 0.325\%. Artinya apabila KI rendah, mengindikasikan bahwa semakin rendah kinerja perusahaan.

Kepemilikan Manajerial

Rata-rata jumlah Kepemilikan Manajerial untuk tahun 2014 sebesar 0,126359\% dan untuk tahun 2015 sebesar 0,119259\%. Kemudian nilai tertinggi dari jumlah Kepemilikan Manajerial pada tahun 2014-2015 adalah VOKS (Voksel Electric Tbk) sebesar 0,7955\%, Semakin tinggi KM maka semakin baik kinerja manajer dalam mengelola perusahaan serta meniningkatkan tujuan perusahaan untuk menghasilkan laba. Selanjutnya nilai terendah 
dari jumlah Kepemilikan Manajerial untuk tahun 2014-2015 adalah yaitu LMPI (Langgeng Makmur Industry Tbk) sebesar 0,0002\%. Artinya apabila KM rendah, mengindikasikan bahwa semakin rendah kepemilikan saham perusahaan yang dimiliki oleh pihak manajemen.

Dewan komisaris Independen

Rata-rata jumlah dewan Komisaris Independen untuk tahun 2014 sebesar 0,383182\% dan untuk tahun 2015 sebesar 0,386364 \%. Kemudian nilai tertinggi dari jumlah Dewan Komisaris untuk tahun 2014-2015 adalah BTON (Beton Jaya Manunggal Tbk), TRST (Trias Sentosa Tbk), KDSI (Kedaung Setia Industrial Tbk), STTP (Siantar Top Tbk), GGRM (Gudang Garam Tbk), dan LMPI (Langgeng Makmur Industry Tbk) sebesar 0.5\%. Artinya semakin besar jumlah Dewan Komisaris Independen memungkinkan untuk mengelola perusahaan dengan baik. Selanjutnya nilai terendah dari jumlah Dewan Komisaris untuk tahun 2014-2015 adalah LION (Lion Metal Works Tbk), LMSH (Lionmesh Prima Tbk), PICO (Pelangi Indah Canindo Tbk), DPNS (Duta Pertiwi Nusantara), APLI (Asiaplast Industries Tbk), ALDO (Alkindo Naratama Tbk), INDS (Indospring Tbk), NIPS (Nippres Tbk), KBLM (Kabelindo Murni Tbk), SKBM (Sekar Bumi Tbk), ULTJ (Ultrajaya Milk Industry and Trading Company Tbk), dan WIIM (Wismilak Inti Makmur Tbk) sebesar $0.33 \%$. Artinya apabila jumlah Komisaris Independen sedikit, mengindikasikan bahwa semakin rendah pengawasan yang dimiliki perusahaan dalam melihat kinerja para direksi.

\section{Dewan Direksi}

Rata-rata jumlah Dewan Direksi untuk tahun 2014-2015 sebesar 4,181818\%. Kemudian nilai tertinggi dari jumlah Dewan Direksi untuk tahun 2014-2015 adalah INDF (Indofood Makmur Sukses Tbk) untuk tahun 2014 sebanyak 9 anggota dan tahun 2015 sebesar 10 anggota. Artinya semakin besar jumlah Dewan Direksi maka semakin baik untuk meniningkatkan tujuan perusahaan untuk menghasilkan laba. Selanjutnya nilai terendah dari jumlah Dewan Direksi untuk tahun 2014-2015 adalah PICO (Pelangi Indah Canindo Tbk) sebanyak 2 anggota. Artinya apabila jumlah Dewan Direksi sedikit, mengindikasikan semakin rendah upaya untuk meningkatkan tujuan perusahaan.

$\underline{\text { Komite Audit }}$

Rata-rata jumlah Komite Audit untuk tahun 2014-2015 sebesar 2,954545\%. Kemudian nilai tertinggi dari jumlah Komite audit untuk tahun 2014-2015 adalah PYFA (Pyridam Farma Tbk) yaitu sebanyak 4 anggota. Artinya semakin banyak jumlah KA maka semakin baik kinerja keuangan perusahaan. Selanjutnya nilai terendah dari jumlah Komite Audit untuk tahun 2014-2015 yaitu PICO (Pelangi Indah Canindo Tbk) dan KDSI (Kedaung Setia Industrial Tbk) sebanyak 2 anggota. Artinya apabila jumlah Komite Audit sedikit, mengidikasikan bahwa semakin rendah kinerja keuangan perusahaan.

Ukuran Perusahaan

Rata-rata jumlah Ukuran Perusahaan untuk tahun 2014 sebesar 27,49091\% dan untuk tahun 2015 sebesar 27,69636\%. Kemudian nilai tertinggi dari jumlah Ukuran Perusahaan pada tahun 2014 adalah GGRM (Gudang Garam Tbk) sebesar 31,7\% dan tahun 2015 adalah INDF (Indofood Sukses Makmur Tbk) sebesar 32.15\%.. Artinya semakin besar Ukuran Perusahaan semakin besar potensi atau kemampuan perusahaan dalam melunasi kewajibannya melunasi hutang. Selanjutnya nilai terendah dari jumlah Ukuran Perusahaan adalah LMSH (Lionmesh Prima Tbk) yaitu untuk tahun 2014 sebesar 25.67\% dan untuk tahun 2015 sebesar 25.62\%. Artinya semakin rendah Ukuran Perusahaan, mengindikasikan bahwa semakin kecil potensi untuk melunasi kewajibannya. Leverage 
Rata-rata jumlah Leverage untuk tahun 2014 sebesar 0,390909 \% dan untuk tahun 2015 sebesar 0,405455\%. Kemudian nilai tertinggi dari jumlah leverage pada tahun 20142015 adalah VOKS (Voksel Electric Tbk) dan KDSI (Kedaung Setia Industrial Tbk) keduanya sama-sama sebesar $0.68 \%$. Artinya Semakin tinggi rasio leverage maka semakin banyak uang kreditur yang digunakan perusahaan untuk menghasilkan laba. Selanjutnya nilai terendah dari jumlah leverage adalah WIIM (Wismilak Inti Makmur Tbk) yaitu untuk tahun 2014 sebesar $0.01 \%$ dan untuk tahun 2015 sebesar $0.02 \%$. Artinya semakin rendah leverage, maka semakin kecil uang kreditur yang digunakan perusahaan untuk menghasilkan laba.

\section{Hasil Uji Asumsi Klasik}

\section{Hasil Uji Normalitas}

Hasil uji asumsi klasik normalitas dilakukan uji statistik Kolmogorov-Smirnov Test. Disajikan pada lampiran 3. Nilai signifikan kolmogorof-smirnov dengan melihat Asmp Sig, suatu data dinyatakan berdistribusi normal jika nilai asymp sig (2-tailed) hasil pengujian Kolmogorov-smirnov lebih besar dari 0.05 atau 5\%. Nilai asymp sig sebesar 0.273 melebihi 0.05 (5\%). Ini berarti bahwa data variabel penggangu memiliki distribusi normal.

\section{Hasil Uji Multikolinieritas}

Hasil uji asumsi klasik multikolinieritas dengan VIF (Variance Inflation Factor) disajikan dan diringkas pada tabel 4.1 berikut:

Tabel 4.1

Hasil Uji Multikolinieritas

\begin{tabular}{|l|r|r|l|}
\hline \multicolumn{1}{|c|}{ Variabel } & Nilai Tolerance & VIF & Simpulan \\
\hline Kepemilikan & .206 & 6.723 & Tidak terjadi multikolinieritas \\
Institusional & & & \\
Kepemilikan & .306 & 5.583 & Tidak terjadi multikolinieritas \\
Manajerial & & & \\
Komisaris Independen & .662 & 1.510 & Tidak terjadi multikolinieritas \\
Dewan Direksi & .752 & 1.331 & Tidak terjadi multikolinieritas \\
Komite Audit & .849 & 1.178 & Tidak terjadi multikolinieritas \\
Ukuran perusahaan & .511 & 1.956 & Tidak terjadi multikolinieritas \\
\hline Leverage & .877 & 1.140 & Tidak terjadi multikolinieritas \\
\hline
\end{tabular}

Sumber: data sekunder diolah peneliti

Hasil Uji Asumsi Klasik Autokorelasi

Hasil uji asumsi klasik autokorelasi menggunakan pendekatan Durbin Watson. Hasilnya disajikan pada Lampiran 3. Hasil uji autokorelasi menggunakan pendekatan Durbin Watson nampak bahwa nilainya sebesar 1.981 terletak di antara 1,55 - 2,46 (Firdaus, 2010). Hal ini mengindikasikan bahwa tidak terjadi autokorelasi.

\section{Hasil Uji Asumsi Klasik Heteroskedastisitas}

Hasil uji asumsi klasik Heteroskedastisitas dengan pendekatan Scatter Plot karena Scatter Plot merupakan sebuah grafik yang biasa digunakan untuk melohat suatu pola hubungan antara 2 variabel, jika titik-titik yang ada pada grafik membentuk pola tertentu yang teratur, maka mengindikasikan terjadi heteroskedastisitas, dan sebaliknya, jika titiktitik yang ada pada grafik tidak membentuk pola tertentu yang teratur (pola tidak beraturan), maka mengindikasikan terjadi heteroskedastisitas (Ghozali, 2013).

\section{Hasil Analisis Regresi Linier Berganda}


Hasil analisi regresi linier berganda disajikan pada lampiran 3. Dari lampiran tersebut dapat dibuat persamaan regresi sebagai berikut:

$$
\begin{aligned}
& Y=\beta_{0}+\beta_{1} X_{1}+\beta_{2} X_{2}+\beta_{3} X_{3}+\beta_{4} X_{4}+\beta_{5} X_{5}+\beta_{6} X_{6}+\beta_{7} X_{7}+\varepsilon \\
& Y=1.581-2.669 \mathrm{KI}-2.073 \mathrm{KM}-0.133 \mathrm{DKI}-0.010 \mathrm{DD}-0.085 \mathrm{KA}+0.049 \mathrm{UP}+0.114 \mathrm{Lev}
\end{aligned}
$$

Selanjutnya diringkas pada Tabel 4.2 berikut:

Tabel 4.2

Hasil Analisis Regresi

\begin{tabular}{|l|c|c|c|}
\hline \multicolumn{1}{|c|}{ Variabel } & Koefisien Regresi & Nilai Signifikansi & Kesimpulan \\
\hline Variabel X1 (KI) & -2.669 & 0.000 & Berpengaruh negatif \\
\hline Variabel X2 (KM) & -2.073 & 0.001 & Berpengaruh negatif \\
\hline Variabel X3 (DKI) & -0.133 & 0.348 & Tidak berpengaruh \\
\hline Variabel X4 (DD) & -0.010 & 0.093 & Tidak Berpengaruh \\
\hline Variabel X5 (KA) & -0.085 & 0.001 & Berpengaruh negatif \\
\hline Variabel X6 (UP) & 0.49 & 0.000 & Berpengaruh positif \\
\hline $\begin{array}{l}\text { Variabel X7 } \\
\text { Leverage) }\end{array}$ & 0.114 & 0.001 & Berpengaruh Positif \\
\hline
\end{tabular}

Sumber: data sekunder diolah peneliti tahun 2016

Berdasarkan pada persamaan yang terdapat pada tabel 4.2 dapat dijelaskan sebagai berikut:

1. Koefisien regresi variabel KI bertanda negative -2.669. Hal ini mengindikasikan bahwa variabel KI berhubungan negatif dengan Manajemen Laba. Jika variabel KI ditingkatkan 1 persen, maka Manajemen Laba turun -2.669 persen.

2. Koefisien regresi variabel KM bertanda negative -2.073. Hal ini mengindikasikan bahwa variabel KM berhubungan negatif dengan Manajemen Laba. Jika variabel KM ditingkatkan 1 persen, maka Manajemen Laba turun -2.073 persen.

3. Koefisien regresi variabel DKI bertanda negatif -0.133 . Hal ini mengindikasikan bahwa variabel DKI berhubungan negatif dengan Manajemen Laba. Jika variabel DKI ditingkatkan 1 persen, maka Manajemen Laba turun -0.133 persen.

4. Koefisien regresi variabel DD bertanda negatif -0.010 . Hal ini mengindikasikan bahwa variabel DD berhubungan negatif dengan Manajemen Laba. Jika variabel DD ditingkatkan 1 persen, maka Manajemen Laba turun -0.010 persen.

5. Koefisien regresi variabel KA bertanda negatif -0.085 . Hal ini mengindikasikan bahwa variabel KA berhubungan negatif dengan Manajemen Laba. Jika variabel KA ditingkatkan 1 persen, maka Manajemen Laba turun -0.085 persen.

6. Koefisien regresi variabel UP bertanda positif 0.49 . Hal ini mengindikasikan bahwa variabel UP berhubungan positif dengan Manajemen Laba. Jika variabel UP ditingkatkan 1 persen, maka Manajemen Laba naik 0.49 persen.

7. Koefisien regresi variabel Leverage bertanda positif 0.114. Hal ini mengindikasikan bahwa variabel Leverage berhubungan positif dengan Manajemen Laba. Jika variabel Leverage ditingkatkan 1 persen, maka Manajemen Laba naik 0.114 persen.

\section{Hasil Uji Hipotesis}

Hasil Uji Hipotesis Pertama 
Hasil uji hipotesis pertama disajikan pada tabel 4.14, nampak bahwa nilai signifikansi uji-F variabel $\mathrm{X} 1, \mathrm{X} 2, \mathrm{X} 3, \mathrm{X} 4, \mathrm{X} 5, \mathrm{X} 6, \mathrm{X} 7$ sebesar 0,002 lebih kecil dari alpa $5 \%$. Hal ini berarti bahwa secara simultan variabel $X 1, X 2, X 3, X 4, X 5, X 6, X 7$ berpengaruh terhadap Y. Dengan demikian, hipotesis pertama yang menyatakan bahwa variabel Kepemilikan Institusional, Kepemilikan Manajerial, Dewan Komisaris Independen, Dewan Direksi, Komite Audit, Ukuran Perusahaan dan Leverage berpengaruh terhadap Manajemen Laba diterima. Hasil penelitian ini sejalan dengan penelitian Abdillah (2016), Hermanto (2015) dan Muhammad (2015) bahwa Kepemilikan Institusional, Kepemilikan Manajerial, Dewan Komisaris Independen, Dewan Direksi, Komite Audit, Ukuran Perusahaan dan Leverage secara bersama sama berpengaruh terhadap Manajemen Laba.

Hasil Uji Hipotesis Kedua

Hasil uji hipotesis kedua pada tabel tersebut nampak bahwa nilai signifikan uji-t atas variabel $X_{1}$ sebesar 0.000 lebih kecil dari alpa 0,05 . Hal ini berarti bahwa secara parsial variabel $X_{1}$ berpengaruh terhadap variabel $Y$. Hasil uji hipotesis kedua yang menyatakan bahwa Kepemilikan Institusional berpengaruh terhadap Manajemen Laba diterima.

Hasil Uji Hipotesis Ketiga

Hasil uji hipotesis ketiga pada tabel tersebut nampak bahwa nilai signifikan uji-t variabl $X_{2}$ sebesar 0,001 lebih kecil dari alpa 0,05. Hal ini berarti bahwa secara parsial variable $\mathrm{X}_{2}$ berpengaruh terhadap variabel $\mathrm{Y}$. Hasil uji hipotesis ketiga yang menyatakan bahwa kepemilikan manajerial berpengaruh terhadap Manajemen Laba diterima.

Hasil Uji Hipotesis Keempat

Hasil uji hipotesis keempat pada tabel tersebut nampak bahwa nilai signifikan uji-t variabel $X_{3}$ sebesar 0,348 lebih besar dari alpa 0,05 . Hal ini berarti secara parsial variabel $X_{3}$ tidak berpengaruh terhadap variabel Y. Hasil uji hipotesis keempat yang menyatakan Dewan Komisaris Independen berpengaruh terhadap Manajemen Laba tidak diterima atau ditolak..

Hasil Uji Hipotesis Kelima

Hasil uji hipotesis kelima disajikan pada tabel nampak bahwa nilai signifikan uji-t variabel $\mathrm{X}_{4}$ sebesar 0.93 lebih besar dari alpa 0,05. Hal ini berarti bahwa secara parsial variabel $\mathrm{X}_{4}$ tidak bepengaruh terhadap variabel $\mathrm{Y}$. Hasil uji hipotesis kelima yang menyatakan bahwa variabel Dewan direksi berpengaruh terhadap Manajemen Laba tidak diterima atau ditolak.

Hasil Uji Hipotesis Keenam

Hasil uji hipotesis keenam disajikan pada tabel tersebut nampak bahwa nilai signifikan uji-t variabel $X_{5}$ sebesar 0.001 lebih kecil dari alpa 0,05. Hal ini berarti bahwa secara parsial variabel $X_{5}$ bepengaruh terhadap variabel $Y$. Hasil uji hipotesis keenam yang menyatakan bahwa variabel komite audit berpengaruh terhadap manajemen laba diterima.

Hasil Uji Hipotesis Ketujuh

Hasil uji hipotesis ketujuh disajikan pada tabel tersebut nampak bahwa nilai signifikan uji-t variabel $\mathrm{X}_{6}$ sebesar 0,000 lebih kecil dari alpa 0,05. Hal ini berarti bahwa secara parsial variabel $\mathrm{X}_{6}$ bepengaruh terhadap variabel $\mathrm{Y}$. Dengan demikian, hipotesis ketujuh yang menyatakan bahwa variabel ukuran perusahaan berpengaruh terhadap manajemen laba diterima.

\section{Hasil Uji Hipotesis Kedelapan}

Hasil uji hipotesis kedelapan disajikan pada tabel tersebut nampak bahwa nilai signifikan uji-t variabel $X_{7}$ sebesar 0,001 lebih kecil dari alpa 0,05. Hal ini berarti bahwa secara parsial variabel $X_{7}$ bepengaruh terhadap variabel $Y$. Hasil uji hipotesis kedelapan 
yang menyatakan bahwa variabel Leverage berpengaruh terhadap Manajemen Laba diterima.

\section{KESIMPULAN DAN SARAN}

Hasil penelitian yang diperoleh dalam penelitian ini yaitu Pengaruh Good Corporate Governance dan Leverage Terhadap manajemen laba adalah sebagai berikut:

1. Secara simultan Good Corporate Governance (GCG) dengan proksi kepemilikan institusional, kepemilikan manajerial, dewan komisaris independen, dewan direksi, komite audit, dan ukuran perusahaan, serta rasio leverage berpengaruh terhadap manajemen laba pada perusahaan manufaktur yang terdaftar di BEI

2. Kepemilikan institusional berpengaruh terhadap manajemen laba pada perusahaan manufaktur yang terdaftar di BEI

3. Kepemilikan manajerial berpengaruh terhadap manajemen laba pada perusahaan manufaktur yang terdaftar di BEI

4. Dewan komisaris independen tidak berpengaruh terhadap manajemen laba pada perusahaan manufaktur yang terdaftar di BEI

5. Dewan direksi tidak berpengaruh terhadap manajemen laba pada perusahaan manufaktur yang terdaftar di BEI

6. Komite audit berpengaruh terhadap manajemen laba pada perusahaan manufaktur yang terdaftar di BEI

7. Ukuran perusahaan berpengaruh terhadap manajemen laba pada perusahaan manufaktur yang terdaftar di BEI

8. Leverage berpengaruh terhadap manajemen laba pada perusahaan manufaktur yang terdaftar di BEI

Saran Untuk Peneliti Selanjutnya:

Penelitian berikutnya dapat menambah variabel-variabel lain yang dapat mempengaruhi majemen laba dan dapat memperkuat hasil penelitian-penelitian yang telah dilakukan sebelumnya.

\section{DAFTAR PUSTAKA}

Abdillah, Selvy Yulita. 2016. Pengaruh Good Corporate Governanace Pada Manajemen Laba (Studi Empiris pada Perusahaan Manufaktur yang Terdaftar di Bursa Efek Indonesia Tahun 2013-2014). Skripsi. Fakultas Ekonomika dan Bisnis Universitas Kanjuruhan Malang.

Amperaningrum, Izzati dan Komala Sari, Intan. 2013. Pengaruh Good Corporate Governance, Leverage, dan Kinerja Keuangan Terhadap Manajemen Laba (Studi Kasus Pada Perusahaan Perbankan Yang Terdaftar Di Bursa Efek Indonesia). Jurnal. Fakultas Ekonomi, Universitas Gunadarma.

Ardiyansyah, Muhammad. 2015. Pengaruh Corporate Governance, Leverage, dan Profitabilitas Terhadap Manajemen Laba pada Perusahaan Manufaktur Sektor Industri Barang Konsumsi Yang Terdaftar Di BEI Periode 2009-2013. Jurusan Akuntansi Fakultas Ekonomi Universitas Maritim Raja Ali Haji.

Azlina, Nur. 2010. Analisis Faktor Yang Mempengaruhi Manajemen Laba. Staff Pengajar Fakultas Ekonomi Universitas Riau.

Ghozali, Imam. 2013. Aplikasi Analisis Multivariate dengan Progam IBM SPSS 19. Edisi Kelima. Universitas Diponegoro. Semarang. 
Guna, Welvin \& Herawaty, Arleen. 2010. Pengaruh Mekanisme GCG, Independensi Auditor, Kualitas Auditor dan Faktor Lainnya terhadap Manajemen Laba. Jurnal Bisnis dan Akuntansi. STIE Trisakti.

Hamdani. 2016. Good Corporate Governance. Jakarta: Mitra Wacana Media.

Herianto. 2013. Pengaruh Good Corporate Governance Terhadap Kualitas Laba Perusahaan Manufaktur yang Terdaftar di Bursa Efek Indonesia. Skripsi. Fakultas Ekonomi dan Bisnis Universitas Hasanudin

Hermanto, Wawan. 2015. Pengaruh kepemilikan Institusional, Ukuran perusahaan, Leverage Terhadap Manajemen Laba (Studi Empiris pada Perusahaan Manufaktur yang Terdaftar di BEI Tahun 2010-2013. Naskah Publikasi. Jurusan Akuntansi Fakultas Ekonomi Dan Bisnis Universitas Muhammadiyah Surakarta.

Jensen, M. C. dan Meckling, W. H. 1976. Theory of The Firm: Managerial Behavior, Agency Cost and Ownership Structure. Journal of Financial Economics, 3, 305-360.

Margaretha, Farah dan Ramadhan, Aditya RIsky, Factor Factor Yang Mempengaruhi Struktur Modal Pada Industry Manufaktur Di BEI, 2010, Jurnal bisnis dan akuntansi

Setiawan, Teguh. 2009. Analisis Pengaruh Mekanisme Good Corporate Governance Terhadap Praktik Manajemen Laba (Pada Perusahaan Manufaktur Yang Terdaftar Di Bursa Efek Indonesia Periode 2005-2007. Jurnal. Kartika Management Consultant.

Subhan, 2011, Pengaruh Good corporate governance terhadap manajemen laba perusahaan perbankan yang terdaftar di BEI, Jurnal bisnis dan akuntansi.

Sugiyono. 2012. Metodologi Penelitian Kuantitatif Kualitatif dan R\&D. Bandung: Alfabetha.

Sugiyono. 2016. Metodologi Penelitian Kuantitatif Kualitatif dan R\&D. Bandung: Alfabetha.

Sulistyanto, S. 2008. Manajemen Laba Teori dan Model Empiris. Jakarta: Gramedia Widiasarana.

Wulan, Restu. Pengaruh Informasi Dan ukuran Perusahaan Terhadap Manajemen Laba. Skripsi. Universitas Widyatama Bandung. 